\title{
TINDAK TUTUR GURU SEBAGAI BENTUK INTERAKSI DALAM PEMBELAJARAN BAHASA INDONESIA DI SMP NEGERI I GUNUNG TULEH KABUPATEN PASAMAN BARAT
}

\author{
Riadaturrahmi $^{1}$, Rosita Hasibuan ${ }^{2}$, Afnita M.Pd. ${ }^{3}$ \\ Mahasiswa Program Studi Pendidikan Bahasa dan Sastra Indonesia FBS UNP \\ Surel: riadaturrahmi6fbs@gmail.com ${ }^{1}$ \\ rosita.hasibuan123@gmail.com² \\ afnita@fbs.unp.ac.id ${ }^{3}$
}

\begin{abstract}
Abstrak
Penelitian yang dilakukan bertujuan untuk mendeskripsikan tuturan guru dalam pembelajaran bahasa Indonesia di kelas saat pembelajaran bahasa Indonesia. Jenis penelitian ini adalah penelitian kualitatif dengan metode deskriptif. Pengumpulan data dilakukan dengan kegiatan menyimak. Data yang disimak tersebut diperoleh dari alat bantu rekaman maupun catatan saat penelitian dilakukan. Tuturan guru diklasifikasikan oleh peneliti menjadi tiga bagian, yaitu tuturan saat membuka pelajaran, tuturan saat menyampaikan pelajaran, dan tuturan saat menutup pelajaran. Berdasarkan penelitian yang dilakukan, dapat disimpulkan bahwa guru lebih sering menggunakan tuturan asertif dan menggunakan bahasa daerah sebagai pengantar pembelajaran.
\end{abstract}

Kata kunci: tuturan, interaksi, guru, pembelajaran.

\section{ABSTRACT}

The research was conducted with the aim of describing teacher's speech in Indonesian learning in class when learning Indonesian. The type of this research is qualitative research with descriptive methods. Data collection is done by listening activities. The data that is observed is obtained from stress devices and notes when the research was examined. Teacher's speech classified by the researcher is devided into three part, namely utterance when giving lessson, when delivering lessons and lessons that are lesson related. Based on research conducted, it can be concluded that teachers often use assertive requirements and use regional language as the language of intstruction.

Keywords: speech, interaction, teacher, and learning.

\section{PENDAHULUAN}

Bahasa Indonesia adalah bahasa persatuan yang harus dikuasai oleh seluruh rakyat indonesia. Sebagai warga negara yang baik sudah sepantasnyalah kita menggunakan bahasa Indonesia tersebut dan membiasakannya dalam kehidupan 
sehari-hari. Namun disamping itu, ada bahasa daerah yang berperan penting dalam kehidupan masyarakat dan harus dilestarikan oleh pemilik bahasa demi mempertahankan budaya bangsa. Dalam ilmu bahasa Indonesia, tindak tutur dipelajari dalam sebuah cabang ilmu bahasa yaitu pragmatik. Dalam tataran pragmati semua jenis tindak tutur memiliki makna dan arti yang berbeda. Tindak tutur memberikan peranan penting dalam proses komunikasi. Konteks yang berbeda akan merubah makna dalam tindak tutur yang sama. Jadi, penggunaan bahasa dalam kegiatan bertutur atau berbicara dapat berpengaruh terhadap maksud ataupun tujuan dari tuturan yang di tuturkan oleh si penutur tersebut.

Austin (1962), menyatakan bahwa pada dasarnya saat seseorang mengatakan sesuatu, berarti dia juga melakukan sesuatu. Artinya, apapun yang dituturkan mempunyai maksud untuk melakukan sesuatu. Sebelum bertutur, si penutur harus mempertimbangkan berbagai kemungkinan tindak tutur yang sesuai dengan konteks posisi penutur, situasi, dan struktur yang ada dalam tuturan tersebut. Subyano (1992:1) mendefinisikan tentang unsur-unsur yang terdapat dalam sebuah tuturan. Antara lain yaitu, siapa berbicara, dengan siapa berbicara, tentang apa, dengan jalur apa, dan ragam bahasa yang mana. Semua tuturan yang diucapkan penutur, baik itu dalam situasi formal maupun nonformal pasti mempunyai maksud dan tujuan tertentu.

Dalam penelitian ini, peneliti melakukan penelitian di SMP Negeri 1 Gunung Tuleh tentang tindak tutur yang digunakan oleh guru dalam berinteraksi saat pembelajaran berlangsung. SMP Negeri 1 Gunung tuleh merupakan sebuah sekolah menengah pertama yang terletak di Kecamatan Gunung Tuleh, Kabupaten Pasaman Barat, provinsi Sumatera Barat. Semua komunikasi yang terjadi dalam proses pembelajaran tidak akan terjadi tanpa adanya bahasa. Dengan bahasa, guru dan siswa bisa melakukan kegiatan bertutur dalam betuk interaksi dalam proses pembelajaran. Dengan bertutur, guru bisa menyampaikan pelajaran kepada siswanya, begitu pula siswa akan mendapatkan pengetahuan dari tuturan guru tersebut sehingga, proses belajar mengajar dapat berjalan dengan baik. Dalam hal ini, tindak tutur berperan penting. Hal tersebut terlihat dari pentingnya bahasa tersebut bagi guru dan siswa. Dengan tindak tutur yang tepat, maka guru bisa menyampaikan pelajaran pada siswanya dan siswanya pun bisa dengan mudah memahami materi yang dipelajari. Alwasilah (1985), menyatakan bahwa ujaran tidak hanya berfungsi sebagai pengungkap unsurunsur kognitif, unsur sikap pun ada dalam setiap bahasa, yaitu unsur memperlihatkan maksud penutur, pikiran, kegiatan, dan sebab penuturannya. Dari pernyataan tersebut daat disimpulkan bahwa tuturan itu merupakan sesuatu yang penting untuk mengungkapkan maksud dari penutur.

SMP Negeri 1 Gunung Tuleh diangkat oleh peneliti sebagai objek penelitian karena dianggap sebagai sekolah yang menggunakan tindak tutur yang masih bercampur dengan bahasa daerah, karena daerahnya yang masih tertinggal. Meski sekolah ter- 
sebut berada di sebuah desa, namun hanya sekolah tersebutlah satusatunya sekolah yang menjadi tempat menimba ilmu di antara belasan desa yang mengelilinginya. Sekolah tersebut sudah mulai menggunakan kurikulum 2013 dan menerapkan full day school. Peneliti melakukan penelitian di sekolah tersebut dengan alasan bahwa sekolah SMP Negeri 1 Gunung Tuleh ini belum pernah diteliti sebelumnya, alasan lainnya yaitu peneliti ingin mengetahui bagaimana tindak tutur guru dalam berinteraksi dengan siswanya saat pembelajaran berlangsung.

Penelitian ini, peneliti merumuskan tiga rumusan masalah, yaitu (1) mendeskripsikan bagaimana tutran guru mengawali sebuah pembelajaran, (2) bagaimana tuturan guru ketika menyampaikan pelajara, dan (3) bagaimana guru mengakhiri pembelajaran.

\section{METODE}

Metode yang digunakan dalam penelitian ini adalah metode deskriptif. Menurut Nabawi (2012:67) metode deskriptif adalah sebuah prosedur untuk memecahkan masalah yang diselidiki dengan menggambarkan atau melukiskan keadaan subyek atau objek penelitian (seseorang, lembaga, masyarakat, dan lain-lain) pada saat sekarang berdasarkan fakta yang tampak atau bagaimana adanya. Jenis penelitiannya adalah penelitian kualitatif. Penelitian kualitatif menurut Sugiyono (2010:1) adalah penelitian yang digunakan untuk menyelidiki, menemukan, menggambarkan, dan menjelaskan kualitas atau keistimewaan dari pengaruh sosial yang tidak dapat dijelaskan, diukur, atau digambarkan dengan melalui pendekatan kuantitatif.

Sumber data dari penelitian ini adalah peristiwa berbahasa atau tindak tutur yang terjadi antara guru dan siswa di SMP Negeri 1 Gunung Tuleh yang melakukan aktivitas bertutur di sekolah umum tersebut. Sekolah tersebut berada di sebuah desa terpencil yang bernama Paraman Ampalu kecamatan Gunung Tuleh, Kabupaten Pasaman Barat.

Penelitian ini, data diperoleh dengan bantuan alat bantu seperti tipe recorder, dan catatan kecil. Dalam meneliti, seorang peneliti harus memiliki sikap yang tekun, hati-hati dan fokus terhadap objek yang diteliti. Hal tersebut untuk menghindari kekeliruan dan ketidaklengkapan data. Seorang peneliti harus menganalisis data dengan seteliti dan sebaik mungkin.

Penelitian ini dilakukan dengan menggunakan dua teknik yaitu teknik pemeriksaan keabsahan data dan triangulasi. Dalam memeriksa keabsahan data, ketekunan seorang peneliti sangat diperlukan. Dengan begitu, data yang diperoleh tidak akan keliru dan peneliti lebih fokus dalam mengamati hal-hal yang dirasa perlu untuk dibuat catatan. Triangulasi dilakukan dengan memamfaatkan peneliti lain untuk melakukan pengecekkan kembali terhadap data yang telah diperoleh agar tidak terjadi kekeliruan atau ketidaklengkapan data.

Langkah-langkah yang harus ditempuh peneliti. pertama, penerjemahan tindak tutur yang telah diperoleh dari lokasi penelitian ke dalam bahasa Indonesia. Kedua, 
menganalisis dan menginterpretasikan tindak tutur yang terjadi di SMP Negeri 1 Gunung Tuleh tersebut. Ketiga, membuat simpulan tentang bentuk tindak tutur bahasa daerah guru dan siswa di SMP Negeri 1 Gunung Tuleh Kabupaten Pasaman Barat.

\section{HASIL DAN PEMBAHASAN}

Dari hasil penelitian yang dilakukan melalui pengamatan langsung, maka dapat dilihat bagaimana seorang guru dalam mengajar di kelas. Bahkan, meskipun yang di ajarkannnya tersebut adalah mata pelajaran Bahasa Indonesia, namun guru di sekolah ini tetap menggunakan bahasa daerah dalam berinteraksi dengan siswanya. Apalagi mata pelajaran yang lain. Padahal, tingkat SMP sudah seharusnya guru membiasakan siswanya dengan menggunakana bahasa pengantar pembelajaran dengan bahasa Indonesia untuk membiasakan siswa menggunakan bahasa Indonesia.

Bahasa Indonesia seharusnya dijadikan bahasa pengantar pembelajaran agar siswa terbiasa menggunakan bahasa persatuan tersebut. Namun faktanya, di sekolah SMP Negeri 1 Gunung Tuleh ini, pendidik masih sering menggunakan bahasa daerah dalam interaksi dengan siswanya.

Menurut mereka, siswa akan lebih termotivasi dalam belajar dan lebih mendalami materi jika mereka menggunkan bahasa daerah sebagai bahasa pengantar dalam pembelajaran. Meski mereka tahu kalau sebaiknya mereka menggunakan bahasa Indonesia saja, namun hal tersebut terpaksa dilakukan demi kelancaran pembelajaran dan ketercapaian tujuan pembelajaran.

Berikut adalah beberapa analisis bagaimana seorang guru dalam mengajar. Mulai dari guru memulai pembelajaran sampai menutup pembelajaran pada hari itu.

\section{Tindak Tutut 1}

\section{Tururan Mengawali Pelajaran}

Dialog tuturan antara guru dan siswa di lokal VIII. B saat pembelajaran bahasa Indonesia pada pukul 08.20 dengan materi teks puisi. Tuturan terjadi bermaksud untuk melakukan pembelajaran mengenai teks puisi, percakapan yang terjadi antara guru dan siswa terkait seputar pengertian teks puisi, strukturnya puisi,dan pengalaman siswa dalam menulis berita.

Guru : Selamat pagi anak-anak!

Siswa : Selamat pagi Buk.

Guru : Bagaimana kabarnya hari ini?

Siswa : Baik Buk.

Guru : Andi, tujia do na liburi?

(ke mana kamu liburan?)

Siswa : Ke kebun sawit buk panen.

Guru :Oh, deges madai.

(oh, baguslah kalau begitu)
Berdasarkan tuturan di atas, terlihat guru menyapa siswanya dengan ucapan selamat pagi, dan kemudian di jawab oleh siswanya dengan ucapan selamat pagi. Namun, saat guru menanyakan kabar siswanya pada hari itu, siswa hanya menjawab tanpa melontarkan pertanyaan balik.

Selain itu, guru terlihat menggunakan bahasa Mandailing untuk bertanya kepada muridnya tersebut. 
Tuturan 2

Tuturan Saat Guru Menyampaikan Pelajaran

Guru : baiklah anak-anak Ibu sekalian, hari ini kita mempelajari tentang teks berita. Siapa yang tahu apa itu teks berita?

Siswa : teks yang di dalamnya mengandung peristiwa tertentu.

Guru : Bagus. Ise dopena na mamboto aha naidokon teks berita i? ( siapa lagi yang tau apa yang dimaksud dengan teks berita?)

Siswa : Saya Buk.

Guru : Ya, coba jelaskan!

Siswa : Teks berita adalah teks yang mengandung segala peristiwa yang terjadi di dunia yang disebarkan melalui media Bu.

Guru : Pintar anak-anak Ibu semuanya. Nari Ibu marsapa, aha sajo ma na tarmasuk struktur ni berita i? (sekarang ibu mau nanya, apa saja yang termasuk struktur teks berita?)

Siswa : Orientasi berita, peristiwa, dan sumber berita Bu.

Guru : Pintar anak ibu semuanya. Kan pala mambaco homu dibagas dapot komu do palajani. Rajin iba balajar di bagas de nak e! (kan kalau kalian mau membaca di rumah, kalian bisa memahami pelajaran tersebut. Rajin

belajar di rumah ya nak!

Siswa : Iya Bu.

\section{Analisis}

Tuturan tersebut terjadi antara guru dan siswa saat pembelajaran berlangsung, di sana telah terjadi interaksi yang sangat baik, apapun yang ditanyakan oleh gurunya, siswa menjawab dengan sopan. Dalam contoh di atas juga ditemukan tuturan asertif, di mana guru menanyakan sesuatu dan dijawab oleh siswa dan kemudian guru memberikan apresiasi kepada siswanya. Selain itu, juga terdapat penggunaan bahasa daerah sebagai pengantar pembelajaran. Namun walaupun demikian, tuturan asertifnya tetap ada. Kurniati dalam penelitiannya menyatakan bahwa:

"Tindak tutur asertif dilihat dari bentuk kalimat dan muatan proposisi, serta berdasarkan pembagian kedua kalimat itu ke dalam informasi lama dan informasi baru."

Dalam tuturan tersebut guru menggunakan bahasa daerah sebagai bahasa pengantar pembelajaran. Hal tersebut terus dilakukan guru dengan tujuan untuk memudahkan siswa memahami materi yang disampaikannya tersebut. Memang jelas terlihat, dengan penggunaan bahasa daerah, ah siswa lebih bersemangat menjawab pertanyaan dari guru dan lebih termotivasi dalam proses pembelajaran. Hal tersebut sesuai dengan pendapat Sitohang dalam penelitiannya menyatakan bahwa selain sebagai bahasa pengantar, beberapa guru menggunakan bahasa daerah sebagai bahasa komunikasi kepada siswa secara individual. Hal ini karena kadang-kadang terdapat siswa 
yang memerlukan pendekatan bahasa yang khusus. Beberapa guru juga mengatakan bahwa bahasa daerah lebih akrab secara emosional dan cukup membantu dalam menyampaikan materi atau hal lain kepada siswa jika dibandingkan bahasa Indonesia.

Berdasarkan hal tersebut, di sekolah ini siswa maupun gurunya masih bergantung dengan bahasa daerah yang mereka miliki.

\section{Tuturan 3}

\section{Tuturan mengakhiri pelajaran}

Guru : Baiklah anak-anak, kalian sudah tau apa itu teks berita, dan juga struktur teksnya. Nah, karena waktu sudah habis, jadi pembelajaran hari ini dicukupkan sampai di sini ya. Rajin baca buku di rumah ya.

Siswa : Baik, bu.

Guru : Assalamu'alaikum anakanak.

Siswa : Walaikumsalam Buk.

Kalimat mengakhiri pelajaran tersebut juga mengandung tuturan asertif, di sana terlihat guru memberikan tuturan yang bersifat positif yang memotivasi siswanya untuk belajar lebih giat lagi Indan siswanya juga memberikan respons dengan sopan.

\section{PENUTUP}

\section{Simpulan}

Penelitian yang dilakukan adalah penelitian kualitatif dengan metode deskriptif. Data penelitian ini diperoleh dari pengamatan langsung yang dilakukan di SMP N 1 Gunung Tuleh, Kabupaten Pasaman Barat, Provinsi Sumatera Barat.

Tindak tutur yang digunakan oleh guru bidang studi Bahasa Indonesia dalam kegiatan pembelajaran di SMP Negeri 1 Gunung Tuleh Kabupaten Pasaman Barat menggunakan tindak tutur asertif. Tuturan yang terjadi selama proses pembelajaran terlihat guru ingin sekali memotivasi siswanya agar belajar dengan lebih giat lagi dengan memberikan apresiasi. Selain itu, guru juga menggunakan bahasa daerah sebagai bahasa pengantar pembelajaran dengan tujuan agar siswa lebih menguasai dan lebih mengerti dengan apa yang di jelaskan oleh guru. Hal tersebut terlihat saat guru bertanya kepada siswa dengan menggunakan bahasa daerah.

\section{Saran}

Bagi peneliti selanjutnya, penelitian ini hendaknya menjadi bahan masukan dan juga perlu diberi tambahan karena penelitian ini merupakan penelitian yang dilakukan pertama kali dan membutuhkan beberapa masukan dan tambahan pada penelitian selanjutnya. Bagi para guru di SMP Negeri 1 Gunung Tuleh, hendaknya lebih ditingkatkan lagi cara memotivasi siswanya dan terus melakukan tuturan asertif tersebut. Serta, memulai menghilangkan bahasa daerah saat pembelajaran, apalagi pembelajaran Bahasa Indonesia. Dengan demikian, maka siswa akan lebih terlatih dan temotivasi untuk menggunakan bahasa Indonesia sebagai bahasa persatuan negara Indonesia. 


\section{DAFTAR PUSTAKA}

Alwasilah, Chaedar. 1985. Sosiologi Bahasa. Bandung: Angkasa

Austin, J.L. 1962. How to do Things with Words. London: Oxford University Press.

Kurniati, L \& Izhar. 2015. Bahasa Ibu dalam Pembelajaran Anak Disekolah. Jurnal Pesona vol. 1 No. 1. https://ejournal.stkipmpringsewu-lpg.ac.id. Diunduh 11 Mei 2019.

Nabawi, Hadari. 2012. Metode Penelitian Bidang Sosial. Yogyakarta. Gajah Mada University Press.
Subyano S.U. 1992. Psikolinguistik Suatu Pengantar. Jakarta. Depdikud

Sitohang, Muston N.M. 2017. Penggunaan Bahasa Daerah Sebagai Pengantar Di Kelas Rendah Sekolah Dasar Di Kota Palangka Raya. Jurnal Suar Betang vol.12 No. 2. https://suarbetang.kemdikbud.go.id. Diunduh 11 Mei 2019.

Sugiyono. 2010. Metode Penelitian Pendidikan

Pendekatan

Kuantitatif, Kualitatif, dan $R \& D$. Bandung: Alfabeta. 